Eur. J. Clin. Chem. Clin. Biochem.

Vol. 30, 1992, pp. 193-196

(C) 1992 Walter de Gruyter \& Co.

Berlin - New York

\title{
Mineral Metabolism in Erythrocytes from Patients with Cystic Fibrosis ${ }^{1)}$
}

\author{
By J. Vormann ${ }^{1}, T$. Günther ${ }^{1}, K$. Magdorf $^{2}$ and $U$. Wahn ${ }^{2}$ \\ ${ }^{1}$ Institut für Molekularbiologie und Biochemie, Freie Universität Berlin \\ ${ }^{2}$ Kinderklinik, Krankenhaus Heckeshorn, Berlin
}

(Received September 9, 1991/January 10, 1992)

Summary: In patients with cystic fibrosis plasma concentrations of $\mathrm{Zn}$ and $\mathrm{Mg}$ were unchanged, plasma $\mathrm{Ca}$ concentrations were somewhat decreased, but plasma $\mathrm{Fe}$ concentrations were drastically reduced; the ratio $\mathrm{Cu} / \mathrm{Fe}$ in plasma was increased. The $\mathrm{Mg}$ and $\mathrm{Zn}$ contents of erythrocytes from patients were unchanged. Therefore, the $\mathrm{Mg}$ and $\mathrm{Zn}$ content of erythrocytes cannot serve for the detection of patients with cystic fibrosis and their heterozygotes, as has been suggested. $\mathrm{Cl}^{-}$-dependent $\mathrm{Mg}^{2+}$ efflux from $\mathrm{Mg}^{2+}$-loaded erythrocytes was not affected in cystic fibrosis. $\mathrm{Na}^{+}$-dependent $\mathrm{Mg}^{2+}$ efflux was increased only in erythrocytes from patients with the most severe clinical symptoms.

\section{Introduction}

It has recently been reported that erythrocytes from children with cystic fibrosis had significantly lower median concentrations of $\mathrm{Na}, \mathrm{Mg}$ and $\mathrm{Zn}$, and a higher median concentration of $\mathrm{Ca}$ than those of healthy control children and the parents of the cystic fibrosis children (1). Based on these results it was suggested that an analysis of these elements can distinguish cystic fibrosis heterozygotes from healthy controls and that the changed "erythrocyte concentrations of these elements reflect a primary defect of the cystic fibrosis disease and very likely an impairment of $\mathrm{Cl}^{-}$transport function related to the $\mathrm{DF}_{508}$ mutation in the cystic fibrosis gene" (1).

In preceding experiments we have characterized $\mathrm{Mg}^{2+}$ efflux from erythrocytes. $\mathrm{Mg}^{2+}$ efflux from erythrocytes comprises amiloride-sensitive $\mathrm{Na}^{+} / \mathrm{Mg}^{2+}$ antiport and $\mathrm{Na}^{+}$-independent $\mathrm{Mg}^{2+}$ efflux which is combined with $\mathrm{Cl}^{-}$efflux for charge compensation. The latter can be inhibited by high extracellular $\mathrm{Cl}^{-}$concentration and by 4-acetamido-4'-isothiocyanatostilbene-2,2'-disulphonic acid $(2,3)$. As an additional

\footnotetext{
1) With financial support by the Deutsche Forschungsgemeinschaft (Sfb 174).
}

proof of the reduced erythrocyte $\mathrm{Mg}$ content, and in view of the fact that a part of $\mathrm{Mg}^{2+}$ efflux depends on a functioning $\mathrm{Cl}^{-}$transport, which might be disturbed in cystic fibrosis, we measured the components of $\mathrm{Mg}^{2+}$ efflux from erythrocytes of patients with cystic fibrosis.

\section{Materials and Methods}

\section{Patients}

Heparinized blood was taken from 15 patients with cystic fibrosis (6 males, 9 females, age range 5-22 years; mean 16). The patients were treated according to their various clinical symptoms. Additionally, they received 3 dragees/day of a multivitamin/mineral preparation (Eunova ${ }^{\circledR}$ ). In addition to other components, each dragee contained $7.3 \mathrm{mg} \mathrm{Fe}^{2+}$. Furthermore, the patients received $40 \mathrm{mg} \mathrm{Zn}$ orotate and $100 \mathrm{mg}$ vitamin $\mathrm{E}$ per day.

For controls, heparinized blood was taken from 4 healthy controls (age 18-38) and 4 patients (age 3-25) not suffering from cystic fibrosis (atopic dermatitis, neuroses).

Blood was centrifuged at $1000 \mathrm{~g}$ for $10 \mathrm{~min}$. The plasma and buffy coat were aspirated. Plasma was taken for the measurement of $\mathrm{Mg}, \mathrm{Ca}, \mathrm{Zn}, \mathrm{Fe}$ and $\mathrm{Cu}$ by atomic absorption spectrophotometry (AAS, Philips, SP 9). The erythrocytes were washed twice with $150 \mathrm{mmol} / \mathrm{l} \mathrm{KCl}$, then haemolysed by adding $750 \mu$ $\mathrm{H}_{2} \mathrm{O}$. An aliquot $(50 \mu \mathrm{l})$ of the haemolysate was taken for determination of haemoglobin by the cyanomethaemoglobin 
method. The remainder was deproteinized by addition of $50 \mu \mathrm{l}$ $750 \mathrm{~g} / 1$ trichloroacetic acid, centrifuged, and the supernatant taken for measurement of erythrocyte $\mathrm{Mg}$ and $\mathrm{Zn}$ by AAS after dilution with $100 \mathrm{~g} / 1$ trichloroacetic acid/1.75 g/l LaCl 3 .

The major part of the erythrocytes was taken for the measurement of $\mathrm{Mg}^{2+}$ efflux, as already described (4). The cells were loaded with $\mathrm{Mg}^{2+}$ by incubating a cell suspension (cell volume fraction 0.1 ) for $30 \mathrm{~min}$ at $37^{\circ} \mathrm{C}$ in $\mathrm{KCl}$ medium (in mmol/l: $140 \mathrm{KCl}, 12 \mathrm{MgCl}_{2}, 50$ sucrose, 5 glucose, 30 Hepes/Tris, $\mathrm{pH}$ 7.4) with the addition of $6 \mu \mathrm{mol} / 1$ of the cation ionophore A23187 dissolved in dimethyl sulphoxide. For removal of the ionophore, the cells were incubated four times in $\mathrm{KCl}$ medium plus $10 \mathrm{~g} / \mathrm{l}$ bovine serum albumin for $10 \mathrm{~min}$ at $37^{\circ} \mathrm{C}$. The $\mathrm{KCl}$ medium was removed by washing the cells twice with cold $\left(4^{\circ} \mathrm{C}\right.$ ) sucrose medium (in mmol/l: 350 sucrose, 5 glucose, 30 Hepes/Tris, $\mathrm{pH}$ 7.4).

$\mathrm{Mg}^{2+}$ efflux was measured by reincubating a cell suspension (cell volume fraction 0.1 ) at $37^{\circ} \mathrm{C}$ in $\mathrm{Mg}^{2+}$-free $\mathrm{NaCl}$ medium (substitution of $\mathrm{KCl}$ in $\mathrm{KCl}$ medium by $140 \mathrm{mmol} / \mathrm{l} \mathrm{NaCl}$ ), $\mathrm{Mg}^{2+}$-free sucrose medium with or without $30 \mu \mathrm{mol} / 1$ of the anion exchange inhibitor 4-acetamido-4'-isothiocyanatostilbene-2,2'-disulphonic acid (Sigma), or $\mathrm{Mg}^{2+}$-free choline $\mathrm{Cl}$ medium (substitution of $\mathrm{KCl}$ in $\mathrm{KCl}$ medium by $140 \mathrm{mmol} / \mathrm{l}$ choline $\mathrm{Cl}$ ).

At the beginning of reincubation and after $30 \mathrm{~min}, 0.5 \mathrm{ml}$ aliquots of the cell suspensions were centrifuged for $1 \mathrm{~min}$ at $10000 \mathrm{~g}$. Aliquots $(100 \mu \mathrm{l})$ of supernatants were diluted with $1 \mathrm{ml} 100 \mathrm{~g} / 1$ trichloroacetic acid/1.75 g/l LaCl 3 , and $\mathrm{Mg}^{2+}$ was measured by AAS. $\mathrm{Mg}^{2+}$ efflux was calculated from the increase of $\mathrm{Mg}^{2+}$ in the reincubation media. $\mathrm{Mg}^{2+}$ efflux was expressed in relation to cell volume. Cell concentration was determined by the haematocrit, and by measuring the haemoglobin released by cell lysis.

\section{Results and Discussion}

Mineral content of plasma and erythrocytes

Plasma concentrations of $\mathrm{Mg}$ and $\mathrm{Zn}$ were not significantly different in controls and patients with cystic fibrosis. The $\mathrm{Ca}$ concentration in the plasma of cystic fibrosis patients was $0.1 \mathrm{mmol} / \mathrm{l}$ lower than in the controls, but it was within the normal range. Some cystic fibrosis patients with expressed maldigestionmalabsorption showed a reduction in plasma $\mathrm{Mg}$. These patients exhibited clinical symptoms of hypomagnesaemia, e.g. paraesthesias.

Plasma Fe concentration was reduced in cystic fibrosis, although the patients had received Fe supplementation for several weeks. Plasma $\mathrm{Cu}$ was increased. The increase in $\mathrm{Cu}$ was not significant. However, there was a significant difference in the $\mathrm{Cu} / \mathrm{Fe}$ ratio between controls and cystic fibrosis patients (tab. 1). This effect may represent an acute phase reaction due to infections.

$\mathrm{Mg}$ and $\mathrm{Zn}$ concentrations in erythrocytes were not significantly different in controls and cystic fibrosis patients (tab. 2); this finding contradicts published data (1).

Tab. 2. $\mathrm{Mg}$ and $\mathrm{Zn}$ content of erythrocytes from patients with cystic fibrosis and controls. Mean \pm SEM. No statistical significance by unpaired Student's t-test.

\begin{tabular}{lll}
\hline & $\mathrm{Mg} \mathrm{mmol} / \mathrm{l}$ cells & $\mathrm{Zn} \mathrm{mmol} / \mathrm{l}$ cells \\
\hline Controls & $2.28 \pm 0.13$ & $0.16 \pm 0.01$ \\
Cystic fibrosis & $2.43 \pm 0.08$ & $0.15 \pm 0.01$ \\
\hline
\end{tabular}

A possible explanation for this discrepancy may be a better alimentary supply of $\mathrm{Mg}$ and $\mathrm{Zn}$ in the cystic fibrosis patients in our study, which were supplemented with $6.3 \mathrm{mg} \mathrm{Zn} /$ day as $\mathrm{Zn}$ orotate. Since the authors of the previous study (1) did not measure serum $\mathrm{Mg}$ and serum $\mathrm{Zn}$ concentrations and since maldigestion-malabsorption is common in cystic fibrosis, this assumption cannot be ruled out. Probably, the decrease in erythrocyte $\mathrm{Mg}$ and $\mathrm{Zn}$ is only a secondary complication of cystic fibrosis, as already suggested for $\mathrm{Zn}$ in cystic fibrosis (5).

Another possible reason for the difference between our findings and those of the previous study may be the method used to determine $\mathrm{Mg}$ and $\mathrm{Zn}$. As measured by particle-induced X-ray emission, $\mathrm{Mg}$ and $\mathrm{Zn}$ in control erythrocytes amounted to 2.84 and 0.34 $\mathrm{mmol} / \mathrm{kg}$ dry weight (1), whereas the $\mathrm{Mg}$ and $\mathrm{Zn}$ contents of erythrocytes measured by atomic absorption spectrophotometry were $2.3 \mathrm{mmol} / 1$ cells for $\mathrm{Mg}$ $(6,7,8,9)$ and $0.15 \mathrm{mmol} / \mathrm{l}$ cells $((10)$, tab. 2$)$ or $0.2-$ $0.3 \mathrm{mmol} / 1$ cells for $\mathrm{Zn}(7,8)$. Measurement of erythrocyte $\mathrm{Ca}$ was omitted in the present investigation, because the published values for erythrocyte $\mathrm{Ca}$ show wide variations.

The true erythrocyte $\mathrm{Ca}$ content is extremely low $(1 \mu \mathrm{mol} / \mathrm{l}$ cells (6)) and is sensitive to various contaminations (6). The major part of erythrocyte $\mathrm{Ca}$ is bound to the external site of the erythrocyte membrane and the extent of its removal varies with the washing procedure (6).

Tab. 1. Concentration of $\mathrm{Mg}, \mathrm{Ca}, \mathrm{Zn}, \mathrm{Fe}$ and $\mathrm{Cu}$ in plasma of patients with cystic fibrosis and controls. Mean $\pm \mathrm{SEM}$. Statistical significance by unpaired Student's t-test. ${ }^{\mathrm{a}}, \mathrm{p}<0.05,{ }^{\mathrm{b}}, \mathrm{p}<0.01$

\begin{tabular}{lllllll}
\hline & $\begin{array}{l}\mathrm{Mg} \\
\mathrm{mmol} / \mathrm{l}\end{array}$ & $\begin{array}{l}\mathrm{Ca} \\
\mathrm{mmol} / 1\end{array}$ & $\begin{array}{l}\mathrm{Zn} \\
\mu \mathrm{mol} / \mathrm{l}\end{array}$ & $\begin{array}{l}\mathrm{Fe} \\
\mu \mathrm{mol} / \mathrm{l}\end{array}$ & $\begin{array}{l}\mathrm{Cu} \\
\mu \mathrm{mol} / \mathrm{l}\end{array}$ & $\mathrm{Cu} / \mathrm{Fe}$ \\
\hline Controls & $0.74 \pm 0.03$ & $2.17 \pm 0.03$ & $11.8 \pm 0.7$ & $16.7 \pm 2.6$ & $19.4 \pm 1.5$ & $1.16 \pm 0.20$ \\
Cystic fibrosis & $0.72 \pm 0.02$ & $2.07 \pm 0.03^{\mathrm{a}}$ & $11.6 \pm 0.5$ & $9.1 \pm 1.2^{\mathrm{a}}$ & $26.6 \pm 3.5$ & $2.92 \pm 0.54^{\mathrm{b}}$ \\
\hline
\end{tabular}


$\mathrm{Mg}^{2+}$ efflux

As an additional test for a potential decrease in erythrocyte $\mathrm{Mg}$ in patients with cystic fibrosis, we measured $\mathrm{Mg}^{2+}$ efflux from $\mathrm{Mg}^{2+}$-loaded erythrocytes. There was an insignificant increase in $\mathrm{Na}^{+}$-dependent $\mathrm{Mg}^{2+}$ efflux, which operates via $\mathrm{Na}^{+} / \mathrm{Mg}^{2+}$ antiport (tab. $3)$. However, when the patients were grouped according to their clinical symptoms $\quad(1=$ mild, $2=$ medium, 3 = severe clinical symptoms (according to Shwachman \& Kulczyzki (11)), erythrocytes with high $\mathrm{Na}^{+} / \mathrm{Mg}^{2+}$ antiport were derived from patients with severe clinical symptoms of cystic fibrosis (fig. 1, tab. 4). Probably, there is a structural alteration in the erythrocyte membrane of these patients, but the mechanism is still unclear. Since most of these patients inhaled amiloride, which inhibits $\mathrm{Na}^{+} / \mathrm{Mg}^{2+}$

Tab. 3. $\mathrm{Mg}^{2+}$ efflux from erythrocytes from patients with cystic fibrosis and controls in $\mathrm{NaCl}$, choline chloride and sucrose medium. 4-Acetamido-4'-isothiocyanatostilbene-2,2'-disulphonic acid (SITS): $30 \mu \mathrm{mol} / 1$.

$\mathrm{Mg}^{2+}$ efflux values in $\mathrm{mmol} / 30 \mathrm{~min} \times 1$ cells. Mean \pm SEM. No statistical significance by unpaired Student's t-test.

\begin{tabular}{|c|c|c|c|}
\hline Medium $\mathrm{NaCl}^{\mathrm{a}}$ & $\begin{array}{l}\text { Choline } \\
\text { chloride }^{\mathrm{a}}\end{array}$ & Sucrose & $\begin{array}{l}\text { Sucrose } \\
+ \text { SITS }\end{array}$ \\
\hline Controls $0.34 \pm 0.03$ & $0.10 \pm 0.01$ & $0.88 \pm 0.05$ & $0.18 \pm 0.02$ \\
\hline $\begin{array}{ll}\text { Cystic } & 0.55 \pm 0.10 \\
\text { fibrosis } & \end{array}$ & $0.11 \pm 0.01$ & $0.92 \pm 0.05$ & $0.16 \pm 0.01$ \\
\hline
\end{tabular}

${ }^{a} \mathrm{Na}^{+} / \mathrm{Mg}^{2+}$ antiport $\left(\mathrm{Mg}^{2+}\right.$ efflux in $\mathrm{NaCl}$ minus $\mathrm{Mg}^{2+}$ efflux in choline chloride medium) is $0.24 \pm 0.04 \mathrm{mmol} / 30 \mathrm{~min} \times 1$ cells for control and $0.44 \pm 0.12 \mathrm{mmol} / 30 \mathrm{~min} \times 1$ cells for cystic fibrosis patients.

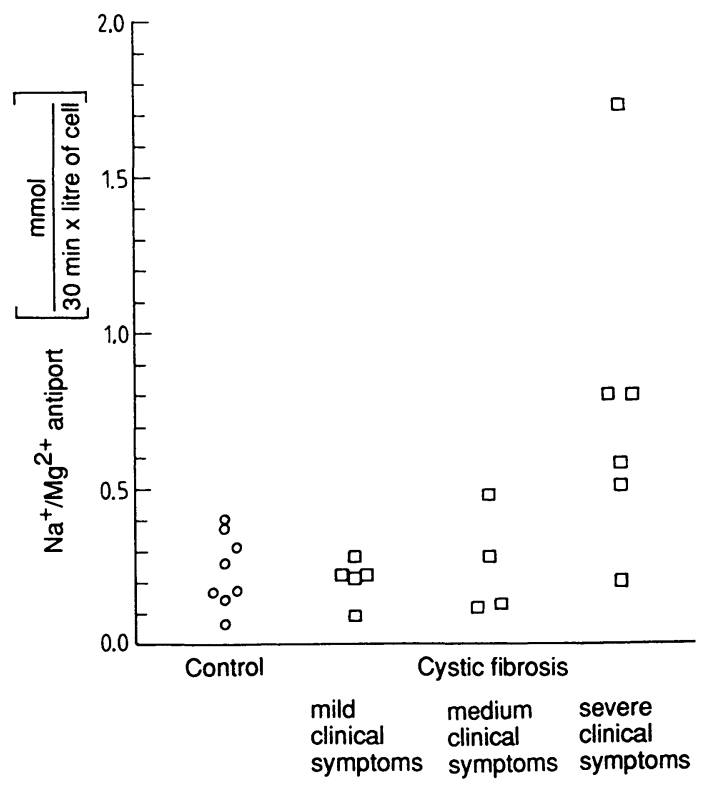

Fig. 1. $\mathrm{Na}^{+} / \mathrm{Mg}^{2+}$ antiport in erythrocytes from controls and patients with cystic fibrosis, grouped according to the severity of disease.

Values represent the difference of $\mathrm{Mg}^{2+}$ efflux in $\mathrm{NaCl}$ medium minus $\mathrm{Mg}^{2+}$ efflux in choline chloride medium.

antiport (7), it may be speculated whether the increased $\mathrm{Na}^{+} / \mathrm{Mg}^{2+}$ antiport in these patients is a compensatory effect. However, the patient with the highest rate of $\mathrm{Na}^{+} / \mathrm{Mg}^{2+}$ antiport did not tolerate amiloride inhalation. $\mathrm{Na}^{+}$-independent $\mathrm{Mg}^{2+}$ efflux, which operates in combination with $\mathrm{Cl}^{-}$efflux, and which is inhibited by 4-acetamido-4'-isothiocyanatostilbene-2,2'-disulphonic acid and $\mathrm{Cl}^{-}$, was not changed in cystic fibrosis (tab. 3 ).

Tab. 4. Age (years), body weight (kg), sex, severity of disease (score 1-3= mild, medium or severe clinical symptoms); erythrocyte $\mathrm{Mg}$ - and $\mathrm{Zn}$-concentration (E-Mg and $\mathrm{E}-\mathrm{Zn}, \mathrm{mmol} / \mathrm{l}$ cells); plasma $\mathrm{Mg}$-concentration (P-Mg, mmol/1); plasma $\mathrm{Zn}$ concentration (P-Zn, $\mu \mathrm{mol} / \mathrm{l})$ and $\mathrm{Na}^{+} / \mathrm{Mg}^{2+}$ antiport (mmol/30 $\mathrm{min} \times 1$ cells) of the patients with cystic fibrosis in the study.

\begin{tabular}{|c|c|c|c|c|c|c|c|c|}
\hline Age & $\begin{array}{l}\text { Body } \\
\text { weight }\end{array}$ & Sex & Score & E-Mg & $\mathrm{E}-\mathrm{Zn}$ & P-Mg & $\mathrm{P}-\mathrm{Zn}$ & $\begin{array}{l}\mathrm{Na}^{+} / \mathrm{Mg}^{2+} \\
\text { antiport }\end{array}$ \\
\hline 5 & 18 & oే & 1 & 2.76 & 0.19 & 0.79 & 16.7 & 0.28 \\
\hline 10 & 30 & 우 & 1 & 3.08 & 0.14 & 0.81 & 11.9 & 0.09 \\
\hline 13 & 58 & 우 & 1 & 2.73 & 0.17 & 0.74 & 11.5 & 0.22 \\
\hline 15 & 62 & o & 1 & 2.34 & 0.13 & 0.81 & 13.2 & 0.22 \\
\hline 20 & 62 & $\sigma$ & 1 & 2.69 & 0.15 & 0.84 & 9.6 & 0.21 \\
\hline 9 & 48 & q & 2 & 2.50 & 0.19 & 0.60 & 9.8 & 0.28 \\
\hline 10 & 29 & q & 2 & 1.92 & 0.12 & 0.69 & 10.3 & 0.12 \\
\hline 10 & 30 & $\sigma$ & 2 & 2.17 & 0.13 & 0.75 & 11.1 & 0.13 \\
\hline 22 & 53 & $q$ & 2 & 2.87 & 0.16 & 0.80 & 10.6 & 0.48 \\
\hline 15 & 36 & 우 & 3 & 2.30 & 0.15 & 0.83 & 11.5 & 0.80 \\
\hline 16 & 29 & 우 & 3 & 2.80 & 0.16 & 0.67 & 10.3 & 0.80 \\
\hline 19 & 50 & 우 & 3 & 2.28 & 0.12 & 0.66 & 15.9 & 0.51 \\
\hline 22 & 50 & $\widehat{0}$ & 3 & 1.96 & 0.14 & 0.70 & 11.2 & 0.58 \\
\hline 23 & 49 & 우 & 3 & 2.40 & 0.18 & 0.54 & 10.9 & 1.73 \\
\hline 23 & 52 & ô & 3 & 2.29 & 0.15 & 0.61 & 9.4 & 0.20 \\
\hline
\end{tabular}


The biochemical defect in cystic fibrosis is a mutation of the cAMP-dependent $\mathrm{Cl}^{-}$channel in airway and intestinal epithelia (12). $\mathrm{Cl}^{-}$-transport in erythrocytes is performed by an anion exchange protein (band 3,

\section{References}

1. Foucard, T., Gebre-Medhin, M., Gustavson, K.-H. \& Lindh, U. (1991) Low concentrations of sodium and magnesium in erythrocytes from cystic fibrosis heterocygotes. Acta Paed. Scand. 80, 57-61.

2. Günther, T. \& Vormann, J. (1989) Characterization of $\mathrm{Mg}^{2+}$ efflux from human, rat and chicken erythrocytes. FEBS Letters $250,633-637$.

3. Günther, T. \& Vormann, J. (1990) Characterization of $\mathrm{Na}^{+}$. independent $\mathrm{Mg}^{2+}$ efflux from erythrocytes. FEBS-Letters $271,149-151$.

4. Günther, T., Vormann, J. \& Höllriegel, V. (1990) Characterization of $\mathrm{Na}^{+}$-dependent $\mathrm{Mg}^{2+}$ efflux from $\mathrm{Mg}^{2+}$. loaded rat erythrocytes. Biochim. Biophys. Acta 1023, $455-461$.

5. Jacob, R. A., Sandstead, H. H., Solomons, N. W., Rieger, C. \& Rothberg, R. (1978) Zinc status and vitamin A transport in cystic fibrosis. Am. J. Clin. Nutr. 31, 638-644.

6. Yoshida, M., Tada, Y., Kasahara, Y., Ando, K. \& Satoyoshi, E. (1986) Ca content of human erythrocytes. What is the true value? Cell Calcium 7, 169-174. capnophorin) (13), which is different from the $\mathrm{Cl}^{-}$ channel of secretory cells. This explains, why the $\mathrm{Na}^{+}$independent $\left(\mathrm{Cl}^{-}\right.$-dependent $) \mathrm{Mg}^{2+}$ efflux is unchanged in erythrocytes from cystic fibrosis patients.

7. Iyengar, G. V., Kollmer, W. E. \& Bowen, H. J. M. (1978) The Elemental Composition of Human Tissues and Body Fluids. Verlag Chemie, Weinheim, New York, pp. 15--16.

8. Documenta Geigy (1975) Wissenschaftliche Tabellen. 7. Auflage, Georg Thieme, Stuttgart, pp. 562-563.

9. Walser, M. (1967) Magnesium metabolism. Rev. Physiol. Biochem. Exptl. Pharmacol. 57, 185-296.

10. Simons, T. J. B. (1991) Intracellular free zinc and zinc buffering in human red blood cells. J. Membrane Biol. 123 , $63-71$.

11. Shwachman, H. \& Kulczyzki, L. L. (1958) Studies made over a 5 to 14 year period of 105 patients with cystic fibrosis Am. J. Dis. Child. 96, 6-12.

12. Franciolini, F. \& Petris, A. (1990) Chloride channels of biological membranes. Biochim. Biophys. Acta 1031, $247-$ 259.

13. Hoffmann, E. K. (1986) Anion transport systems in the plasma membrane of vertebrate cells. Biochim. Biophys. Acta 864, 1-31.

Priv.-Doz. Dr. Jürgen Vormann Institut für Molekularbiologie und Biochemie Freie Universität Berlin Arnimallee 22

W-1000 Berlin 33

Bundesrepublik Deutschland 